American Journal of Agricultural and Biological Sciences 4 (2): 118-122, 2009

ISSN 1557-4989

(C) 2009 Science Publications

\title{
Membrane Binding Activity with Virus in White Spot Syndrome Virus-Infected Fenneropenaeus chinensis
}

\author{
Liu Qing-hui, Huang Jie, Chen Ting, Yang Bing \\ Yellow Sea Fisheries Research Institute, \\ Chinese Academy of Fishery Sciences, Qingdao, 266071, People's Republic of China
}

\begin{abstract}
Problem Statement: White Spot Syndrome Virus (WSSV) is one of the most disastrous pathogens in shrimp culture, having caused high mortality in many cultured shrimp species. It is well known that the most important step of viral infection is cell attachment. Approach:Therefore determining the binding activity of shrimp cells to WSSV is an important to evaluate anti-infection ability and understanding the procedure of a viral infection. So this study aims to analyze binding activity of cell membrane with WSSV in shrimp of Fenneropenaeus chinensis ( $F$. chienesis). WSSV was used to stimulate $F$. chinensis and binding activity in gills, muscle and hepatopancreas with virus within the procession of WSSV was measured. Results: The results showed that binding activity in gills with WSSV within infection stage (0-96 h) had no significant change. The highest binding activity was attained after infection $24-48 \mathrm{~h}$ in muscle. The binding activity in hepatopancreas with WSSV was lower during infection stage (0-96 h). Conclusion/Recommendation: The higher binding activity of WSSV to gills and muscle indicated that gills and muscle are the importance target tissue for WSSV infection. This suggested that receptor of WSSV existed in gills and muscle.
\end{abstract}

Key words: White spot syndrome virus, Fenneropenaeus chinensis, binding activity, Infection

\section{INTRODUCTION}

White Spot Syndrome Virus (WSSV) is one of the most disastrous pathogens in shrimp culture, having caused high mortality in many cultured shrimp species $^{[1]}$. White spot syndrome virus-positive cells occur initially in the stomach, gill, lymphoid organ, cuticular epidermis and hepatopancreas and spread rapidly to other organs during a WSSV infection ${ }^{[2,3]}$. The immune corrected factor and enzyme activity infected by WSSV were evaluated ${ }^{[4,5]}$.

It is well known that the most important step of viral infection is cell attachment. Therefore determining the binding activity of shrimp cells to WSSV is an important to evaluate anti-infection ability and understanding the procedure of a viral infection. Many previous study mainly focused on physiological response of prawns such as total protein content, haemocyte count, phenoloxidase (PO) activity, phagocytic index, release of reactive oxygen intermediates and antibacterial activity, superoxide dismutase (SOD), alkaline phosphatase (ALP), acid phosphatase (ACP) activities ${ }^{[6,7]}$. However, cell membrane binding activity with WSSV could be another criterion to be considered when selecting breed. In shrimp, no data is available on binding activity in relation to WSSV. The present study aims to analyze binding activity of cell membrane with WSSV in shrimp of Fenneropenaeus chinensis.

\section{MATERIALS AND METHODS}

Shrimp and challenge experiments: Experimental Chinese shrimp (Penaeus chinensis), body length $12.32 \pm 1.23 \mathrm{~cm}(\mathrm{n}=60)$ and body weight $16.33 \pm 4.40 \mathrm{~g}$ were obtained from a shrimp farm and held in tanks for $10 \mathrm{~d}$ prior to challenge experiments. WSSV was injected into the second abdominal segment. Muscle tissue, gills, hepatopancreatic tissue and hemolymph of 6 individual shrimp from both the control group (injected $0.9 \% \mathrm{NaCl}$ ) and the challenge group were collected at various times (from 0-72 h) after challenge. Haemolymph was withdrawn from the ventral sinus of the first abdominal segment into an equal volume of anticoagulant $\left(27 \mathrm{mmol} \mathrm{mL}^{-1}\right.$ sodium citrate, $336 \mathrm{mmol} \mathrm{mL} \mathrm{m}^{-1} \mathrm{NaCl}, 115 \mathrm{mmol} \mathrm{mL}^{-1}$ glucose, 9 mmol mL $\mathrm{mL}^{-1}$ EDT, $\mathrm{pH} 7.0$ ), while muscle tissue and gills were harvested by dissection.

Corresponding Author: Liu Qing-hui, Key Laboratory for Sustainable Utilization of Marine Fisheries Resources, Ministry of Agriculture, Yellow Sea Fisheries Research Institute, Chinese Academy of Fishery Sciences, Qingdao, 266071, People's Republic of China Tel: 086-0532-85823062 
Virus preparation: Tissues $(1 \mathrm{~g})$ from $P$. chinensis confirmed for WSSV infection by DNA dot-blot assay were homogenized in $5 \mathrm{~mL}$ TE buffer $(20 \mathrm{mM}$ Tris$\mathrm{HCl}$ and $400 \mathrm{mM} \mathrm{NaCl}, \mathrm{pH}$ 7.4). After centrifugation at $2000 \times \mathrm{g}$, the supernatant was diluted to $1: 100$ with $0.9 \%$ $\mathrm{NaCl}$ and filtered $(0.22 \mathrm{~mm}$ filter). This crude WSSV extract solution was stored at $-70^{\circ} \mathrm{C}$ as the challenge inoculum.

DNA purification: Shrimp gill or muscle tissue $(100 \mathrm{mg})$ was placed in a $1 \mathrm{~mL}$ Eppendorf tube with $300 \mu \mathrm{L}$ TE buffer (10 M Tris-HCL, 1 M EDTA, pH 8.0) and homogenized using a sterile stick. After boiling for $10 \mathrm{~min}$, the homogenates were clarified by centrifugation at $130 \mathrm{~g}$ for $10 \mathrm{~min}$ at $4^{\circ} \mathrm{C}$. Nucleic acids were flocculated by adding $500 \mu \mathrm{L} 100 \%$ ethanol and pelleted by centrifugation at $10,000 \mathrm{~g}$ for $10 \mathrm{~min}$ at $4^{\circ} \mathrm{C}$. The pellets were then washed with $500 \mu \mathrm{L} 70 \%$ ethanol and re-pelleted by $10 \mathrm{~min}$ centrifugation at $10,000 \mathrm{~g}$ at $4^{\circ} \mathrm{C}$. Then pellets were dissolved in $80 \mu \mathrm{L}$ of TE buffer (10 mM Tris-HCL, $1 \mathrm{mM}$ EDTA, pH 8.0) and kept at $-20^{\circ} \mathrm{C}$.

PCR amplification: A primer set for WSSV was designed (W1: 5'-TATTGTCTCTCCTGACGTAC-3, W2: 5'-CACATTCTTCACGAGTCTAC-3') based on the WSSV genomic sequence which generated a 300-bp PCR product. PCR reactions were carried out in a $20 \mu \mathrm{L}$ reaction mixture containing $2.5 \mu \mathrm{L} 10 \times \mathrm{PCR}$ buffer, $1.5 \mu \mathrm{L} 25 \mathrm{mM} \mathrm{MgCL} 2,0.5 \mu \mathrm{L} 10 \mathrm{mM}$ of each of four nucleotides, $2 \mu \mathrm{L}$ of $10 \mathrm{mM}$ of the two primers, $0.5 \mu \mathrm{L}$ Tag DNA polymerase (Promega, France), $13.5 \mu \mathrm{L}$ diethyl pyrocarbonate (DEPC)-treated water and $1 \mu \mathrm{L}$ of the template DNA. PCR conditions were as follows: $95^{\circ} \mathrm{C}$ for $5 \mathrm{~min}$ followed by 30 cycles of $95^{\circ} \mathrm{C}$ for $40 \mathrm{~s}$, $55^{\circ} \mathrm{C}$ for $40 \mathrm{~s}$ and $72^{\circ} \mathrm{C}$ for $1 \mathrm{~min}$ with a final extension for $2 \mathrm{~min}$ at $72^{\circ} \mathrm{C}$. PCR reaction products $(5 \mu \mathrm{L})$ were mixed with $1 \mu \mathrm{L}$ of gel buffer and run on $1 \%$ agarose gels, followed by UV examination in Genefinder ${ }^{\mathrm{TM}}$.

SDS-PAGE analysis: The procedure for discontinuous, denaturing gel electrophoresis was carried out in trisglycine buffer according to the method of Laemmli (1970). The gels were stained with Comassie Brilliant Blue R-250 (CBB) and included a premixed molecular weight marker with proteins ranging from 14.4-97.4 $\mathrm{kDa}$.

Extraction of membrane proteins in gills, muscle and hepatopancreas: At various stages post injection challenge (i.e., 0, 12, 24, 48 and $72 \mathrm{~h}$ ), gills, muscle and hepatopancreas of shrimp $(\mathrm{n}=6)$ were minced in $250 \mathrm{mM}$ sucrose, $10 \mathrm{mM}$ Hepes, $1 \mathrm{mM}$ EDTA, $0.1 \mathrm{mM}$ PMSF, pH 7.2 homogenized and centrifuged at 600 and
$8,000 \mathrm{~g}$ for $10 \mathrm{~min}$ respectively. The supernatants were centrifuged at $100,000 \mathrm{~g}$ for $20 \mathrm{~min}$ in order to sediment the membrane proteins. Then the sediment was resuspended in PBS. All subsequent steps were carried out at $0-4^{\circ} \mathrm{C}$. The protein concentration was estimated by measuring the Optical Densities (OD) at $280 \mathrm{~nm}$. The purity of the membrane proteins was evaluated by negative-staining transmission electron microscopy.

Virus production, purification and DIG-labeled: The virus used in this study was isolated from infected Penaeus monodon shrimps from China. Infected tissue was homogenized in Penaeid Physiological Buffer (PPB). The homogenates were centrifuged at $7000 \mathrm{rpm} \mathrm{min}{ }^{-1}$ (RP65T-856, Hitachi) for $20 \mathrm{~min}$ at $4^{\circ} \mathrm{C}$, the supernatant was recentrifuged at $25000 \mathrm{rpm} \mathrm{min}^{-1}$ (RP65T-856, Hitachi) for $60 \mathrm{~min}$ at $4^{\circ} \mathrm{C}$ and sediment was re-suspended in PPB (contain 35\% sucrose). After centrifugation at $7000 \mathrm{rpm} \min ^{-1}$ for $10 \mathrm{~min}$, the supernatant was over layered onto the top of a $35 \%$ $62 \%(\mathrm{~W} / \mathrm{W})$ (RPS65T-704, Hitachi) continuous sucrose gradient and centrifuged at $36000 \mathrm{rpm} \mathrm{min}{ }^{-1}$ for $3 \mathrm{~h}$ at $4^{\circ} \mathrm{C}$. After centrifugation, viral band was visualized by top illumination and was removed using a pipette. The viral fraction was diluted in PPB and centrifugation at $25000 \mathrm{rpm} \min ^{-1}$ for $1 \mathrm{~h}$ at $4^{\circ} \mathrm{C}$. The pellet was then resuspended in PBS. Then about 20 times membrane protein was mixed with Digoxigenin (DIG) $(20 \mathrm{mg}$ dissolved in $1 \mathrm{~mL}$ DMSO) and redundant DIG was removed through Sephadex G-50 column.

Binding assay of extraction membrane protein with WSSV by ELISA: A $10 \mu \mathrm{g} \mathrm{mL}^{-1}$ solution of extraction membrane protein of gills, muscle and hepatopancreas was prepared. The polystyrene 96-well plate was covered with $100 \mu \mathrm{L}$ extract membrane protein solution (diluted 1:15 with PBS) as the final volume in each well and incubated overnight at $4{ }^{\circ} \mathrm{C}$. Antigen solution was removed and the wells were washed three times with PBS. To each well was added $250 \mu \mathrm{L}$ MPBS (5\% Nonfat milk + PBS) and the plates were incubated for $2 \mathrm{~h}$ at room temperature. After washing the wells with PBS twice, $100 \mu \mathrm{L}$ DIG-labeled WSSV was added diluted with MPBST (Tween 20, 0.1\% (w/v)) to each well for $2 \mathrm{~h}$ at room temperature. Then the wells were washed with PBST and PBS five times respectively. Anti-DIGFab-HRP diluted in MPBS (1:3000) was added at room temperature for $1 \mathrm{~h}$. The wells were washed with PBST and then PBS for five times. The substrate of $75 \mu \mathrm{L}$ OPD was added to each well and incubated at $37^{\circ} \mathrm{C}$ until color appeared. The reaction was stopped by the addition of $50 \mu \mathrm{L}$ of $1 \mathrm{M} \mathrm{H}_{2} \mathrm{SO}_{4}$ to each well. The 
absorbance at $492 \mathrm{~nm}$ was read with $850 \mathrm{~nm}$ as reference. BSA $\left(10 \mu \mathrm{g} \mathrm{mL}^{-1}\right)$ was as a control.

\section{RESULTS}

Detection of shrimp infection: Following injection with WSSV, the first shrimp mortality was recorded at $24 \mathrm{~h}$ post-injection (p.i.). The presence of viral genomic DNA was determined by PCR in living shrimp sampled after injection. The expected band (i.e., at $300 \mathrm{bp}$ ) for WSSV infection (i.e., a positive result) was observed with the viral inoculum and with WSSV-injected shrimp at $12 \mathrm{~h}$ in gills and muscle (Fig. 1 and 2). The band was never obtained with the control shrimp.

Extraction cell membrane and SDS-PAGE analysis: Extraction membrane protein was negative stained and observed by electron micrograph. Membrane proteins in gills showed typical vacuolar. Membrane proteins in muscle were homogenous and larger membrane proteins were showed in hepatopancreas. Microscopy analysis indicated higher purity of extraction membrane proteins in gills, muscle and hepatopancreas (Fig. 3).

SDS-PAGE analysis of cell membrane in gills, muscle and hepatopancreas: SDS-PAGE of the membrane protein stained with coomassie blue revealed the presence of several proteins in gills, muscle and hepatohesis with a wide range of molecular masses.

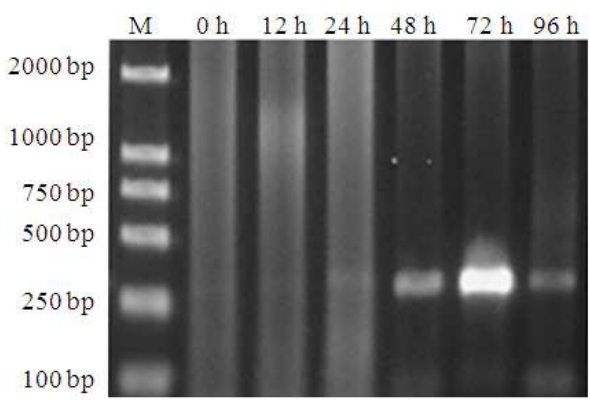

Fig. 1: Detection of WSSV genome by PCR in gills

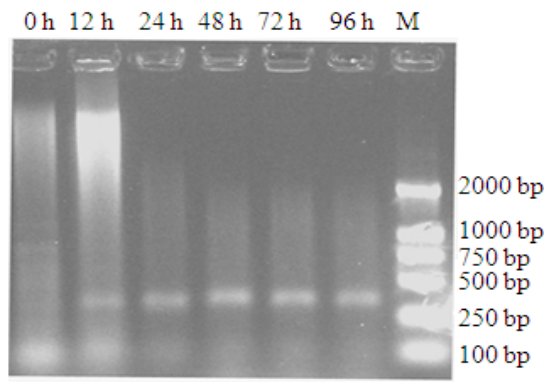

Fig. 2: Detection of WSSV genome by PCR in muscle Protein bands in gills with apparent molecular mass of $171 \mathrm{kD}$ (band 1), $157 \mathrm{kD}$ (band 2), $145 \mathrm{kD}$ (band 3), $139 \mathrm{kD}$ (band 4), $122 \mathrm{kD}$ (band 5), $101 \mathrm{kD}$ (band 6), $86 \mathrm{kD}$ (band 7), $78 \mathrm{kD}$ (band 8), $65 \mathrm{kD}$ (band 9), $60 \mathrm{kD}$ (band 10), $50 \mathrm{kD}$ (band 11), $42 \mathrm{kD}$ (band 12), $39 \mathrm{kD}$ (band 13), $37 \mathrm{kD}$ (band 14), $33 \mathrm{kD}$ (band 15), $31 \mathrm{kD}$ (band 16) were present (Fig. 4).The main protein bands in muscle were $165 \mathrm{kD}$ (band 1), $157 \mathrm{kD}$ (band 2), $152 \mathrm{kD}$ (band 3), $139 \mathrm{kD}$ (band 4), $101 \mathrm{kD}$ (band 5), $93 \mathrm{kD}$ (band 6), $86 \mathrm{kD}$ (band 7), $78 \mathrm{kD}$ (band 8), $66 \mathrm{kD}$ (band 9), $58 \mathrm{kD}$ (band 10), $51 \mathrm{kD}$ (band 11), $48 \mathrm{kD}$ (band 12), $44 \mathrm{kD}$ (band 13), $39 \mathrm{kD}$ (band 14), $36 \mathrm{kD}$ (band 15), $34 \mathrm{kD}$ (band 16), $32 \mathrm{kD}$ (band 17), $31 \mathrm{kD}$ (band 18), $29 \mathrm{kD}$ (band 19) (Fig. 4). Protein bands of $170 \mathrm{kD}$ (band 1), $152 \mathrm{kD}$ (band 2), $139 \mathrm{kD}$ (band 3), $120 \mathrm{kD}$ (band 4), $88 \mathrm{kD}$ (band 5), $65.5 \mathrm{kD}$ (band 6), $58 \mathrm{kD}$ (band 7), $45 \mathrm{kD}$ (band 8), $35 \mathrm{kD}$ (band 9), $30 \mathrm{kD}$ (band 10), 29.3 kD (band 11) were present in hepatopancreas (Fig. 4).

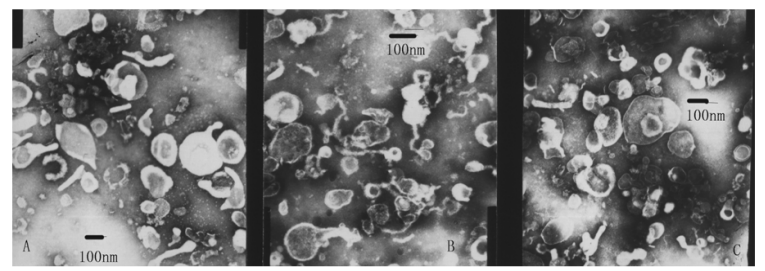

Fig. 3: Ultra-structure of membrane fragments from gills, muscle and hepatohesis. Outer membranes were isolated in materials and methods. The membrane were concentrated by ultracentrifugation. (A): Gills; (B): Muscle; (C): Hepatohesis, The bar represents $100 \mathrm{~nm}$

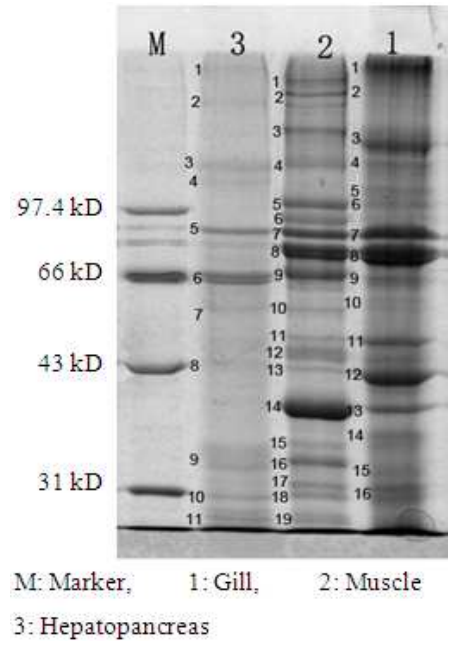


Fig. 4: SDS-PAGE analysis of membrane protein in gills, muscle and hepatopancreas of $P$. chinensis

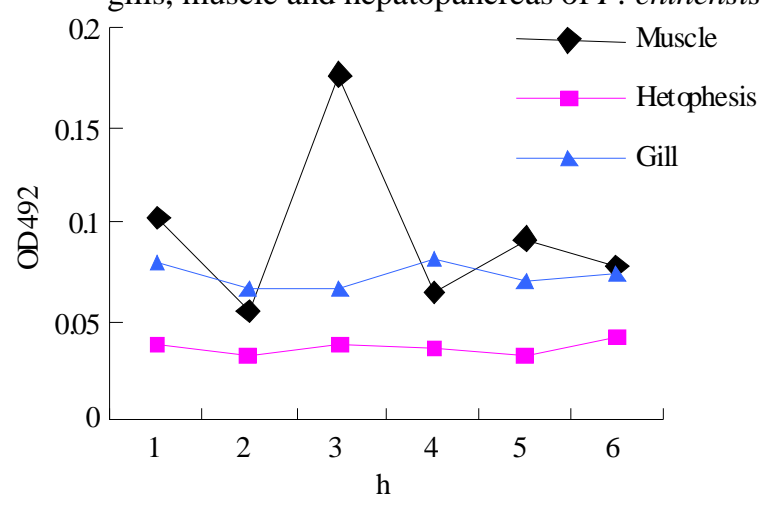

Fig. 5: The binding activity of gill, muscle and hepaceres with Dig-labeled WSSV $(1,2,3,4,5$, 6 in $\mathrm{X}$ axis indicated infection hours of 0,12 , $24,48,72$ and $96 \mathrm{~h}$ )

Binding activity of cell membrane in different tissues with WSSV: The ability of WSSV adhere to cell membrane of gills, muscle and hepatopancreas was evaluated. Cell membrane from gills, muscle showed a higher level of adhesion activity than cell membrane from hepatopancreas. There was no significant change of WSSV binding activity with cell membrane in gills during the stage of WSSV infection $(0-96 \mathrm{~h})$. The highest binding activity was attained in cell membrane of muscle after $24 \mathrm{~h}$ infection. WSSV binding to cell membrane of hepatopancreas was kept at low level during whole infection stage (0-96 h) (Fig. 5).

\section{DISCUSSION}

WSSV is the most devasting viral pathogen of cultured Penaeid shrimp (Penaeus spp.) worldwide ${ }^{[8,9]}$. The virus has a wide host range among crustances and infects all commercially important species of Penaeid shrimp ${ }^{[8]}$.

Receptor binding is only the first step in the infection process. The virus, or the virus genome alone, then has to enter the cell, a process that requires translocation of the genome or a sub-viral particle across the membrane into the cytoplasm and in some cases, into the nucleus. Unlike plant viruses, most animal and bacterial viruses attach to specific cellular receptors that, in part determine host range and tissue tropism. Some viruses recognize very specific molecules (e.g., adhesion molecule) whereas other viruses recognize widely distributed chemical groups. The tissue distribution of the receptor will in part determine the tropism of the virus and hence, the symptoms of the infection. Similarly, species differences between receptor molecules can limit host range.

An interesting observation was that WSSV bound well to gills and muscle. This also indicates that WSSV adhesion may be in specificity tissue. The binding to gills and muscle appeared to be specific since the binding of WSSV to BSA was significantly less (data not shown). The higher binding activity of WSSV to gills and muscle indicated that gills and muscle are the importance target tissue for WSSV infection.

This study indicates that adhesion does indeed correlate to some extent with the presence of receptor. The present data make it clear that adhesion depend on specific tissue. It seems reasonable to deduced that binding activity was corrected with receptor. In view of this study, it is tempting to speculate receptor is of saturated. This research was initiated to test a working hypothesis that the adhesion of WSSV to shrimp cell was the result of the specific interaction between the virus adhesion and a receptor on the gills and muscle surface.

\section{ACKNOWLEDGEMENT}

This study was supported by the National Science Foundation of China (Grant 30871942), the National Basic Research Program (973) of China (Grant 2006CB101801) and the High Technology Development Program of China (863)(Grant 2006AA100312).

\section{REFERENCE}

1. Lightner, D.V., 1996. A Handbook of Pathology and Diagnostic Procedures for Diseases of Penaeid Shrimp. World Aquaculture Society, Baton Rouge, LA., USA., ISBN: 10: 0962452998, pp: 350.

2. Chang, P.S., C.F. Lo, Y.C. Wang and G.H. Kou, 1996. Identification of white spot syndrome assocaated baculovirus (WSBV) target organs in shrimp, Penaeus monodon, by in situ hybridization. Dis. Aquat. Organ., 27: 131-139. http://cat.inist.fr/?aModele=afficheN\&cpsidt=2479869

3. Zhang, Z.F., M.Y. Shao and K.H. Kang, 2005. Changes of enzyme activity and hematopoiesis in Chinese prawn Fenneropenaeus chinensis (Osbeck) induced by white spot syndrome virus and zymosan A. Aquacult. Res., 36: 674-681. http://www.cababstractsplus.org/abstracts/Abstract. aspx $? \mathrm{AcNo}=20053127587$

4. Mohankumar, K. and P. Ramasamy, 2006. White spot syndrome virus infection decreases the activity of antioxidant enzymes in Fenneropenaeus 
indicus. Virus Res., 115: 69-75. http://www.ncbi.nlm.nih.gov/pubmed/16139913

5. Van de Braak, C.B.T., M.H.A. Botterblom, E.A. Huisman, M.H.A. Rombout and W.P.W. Van der Knaap, 2002. Preliminary study on haemocytic responses to white spot syndrome virus infection in black tiger shrimp (Penaeus monodon). Dis. Aquat. Organ., 51: 149-155. http://www.ncbi.nlm.nih.gov/pubmed/12363087

6. Bache're, E., E. Mialhe and J. Rodriguez, 1995. Identification of defense effectors in the haemolymph of crustaceans with particular reference to the shrimp Penaeus japonicas (Bate): Prospects and applications. Fish Shellfish Immunol., 5: 597-612. DOI: 10.1016/S10504648(95)80044-1

7. Rodriguez, J. and G. Le Moullac, 2000. State of the art of immunological tools and health control of penaeid shrimp. Aquaculture, 191: 109-119. http://cat.inist.fr $/$ ?aModele $=$ afficheN\&cpsidt $=1497$ 642

8. Flegel, T.W., 1997. Major viral diseases of black tiger prawn (Penaeus monodon) in Thailand. World J. Microbiol. Biotechnol., 13: 433-442. http://cat.inist.fr $/$ ?aModele $=$ afficheN\&cpsidt $=2762$ 544

9. Krishna, R.P., K.G. Rao, P. Rao and P.H. Babu, 1997. White spot disease. World Aquac., 12: 14-19. 